\title{
Accounting Guidelines Implementation: A Study on Economic Development of Islamic Boarding Schools
}

\author{
Lukfiah Irwan Radjak ${ }^{1}$, Yustina Hiola ${ }^{1}$ \\ ${ }^{1}$ Universitas Muhammadiyah Gorontalo, Indonesia
}

Received: October 24, 2020

Revised: October 31, 2020

Accepted: November 2, 2020

Abstract

The development of Islamic boarding schools is one of the targets for sharia economic development which is based on the understanding of the halal value chain where the development of Islamic economics and finance summarizes various initiative programs including the development of Islamic boarding schools. The purpose of this study is to describe how the implementation of the Islamic Boarding School Accounting Guidelines at Al Huda Islamic Boarding School which is more focused on the readiness of HR at Al Huda Islamic Boarding School in applying the Islamic Boarding School Accounting Guidelines. The Al Huda Islamic boarding school was chosen as the research locus because the Al Huda Islamic Boarding School was appointed by Bank Indonesia Gorontalo Representative Office as a pilot project for the Pesantren (Islamic Boarding School) which applies the Islamic Boarding School Accounting Guidelines. The stages of the research method began with observations and results of interviews with informants from the board of the Al-Huda Islamic Boarding School. The results showed that there was a desire to apply these guidelines in the Al-Huda Islamic boarding school. Even though treasurers, secretaries and operators do not have a basic knowledge of the Economics of Accounting, the existing human resources are ready to apply the Pesantren accounting guidelines, of course, adjusting to the needs of the Al-Huda Islamic boarding school. The author sees that there is no urgency in implementing Islamic boarding school accounting guidelines at the Al-Huda Islamic boarding school because the reporting entity is the foundation that houses the Al-Huda Islamic boarding school, the Al Huda Islamic Education and Da'wah Foundation, Gorontalo. The foundation is fully responsible for the donors or the community.

Keywords: Accounting Guidelines, Economic Development, Islamic Boarding Schools

\section{Introduction}

The development of Islamic boarding schools is one of the targets for sharia economic development which is based on the understanding of the halal value chain where the development of Islamic economics and finance summarizes various initiative programs including the development of Islamic boarding schools. Pesantren (Islamic Boarding School) have a strategic role (Herdiansyah et al., 2016; Sari, 2017). Increasing the economic independence of pesantren will not only provide capabilities in the economic aspect but also in terms of creating human resources who have good character and are also reliable in the economic field (Bawono, 2019). As the flow of modernization progresses, it is hoped that pesantren (Islamic Boarding School) will be more adaptive to the developments of the times. Advanced Islamic boarding schools can be seen from the quality of good resource 
management that supports the creation of good governance (Fauzi, 2019; Purwanto \& Supriadi, 2019). One of the resources that must be managed properly is financial resources, in this case accounting records.

In the Islamic Boarding School Accounting Guidelines, pesantren is still positioned as a nonprofit institution. Islamic boarding schools that have business institutions that are legal entities, whose financial records and reporting comply with existing standards (PSAK). Islamic Boarding School Accounting Guidelines refers to the Financial Accounting Standards for Entities without Public Accountability (SAK ETAP). This accounting guideline is expected to facilitate Islamic boarding schools in preparing their financial reports, so that at least the pesantren can present financial position reports, activity reports, cash flow reports and notes on financial statements.

The government hopes that Islamic boarding schools in Indonesia can apply these accounting guidelines to their respective entities. But the question is, are Islamic boarding schools in Indonesia ready to start tidying up? Are there adequate human resources in each pesantren to start carrying out various accounting activities in their entities according to these guidelines? Of course this has become a matter of consideration for the government, in this case Bank Indonesia as a government institution that has distributed grants to Islamic boarding schools in Indonesia. Bank Indonesia made various structured and measured efforts so that this accounting guideline could be applied to all Islamic boarding schools in Indonesia, starting with the pesantren guided by Bank Indonesia as a pilot project.

This study focuses on the readiness of human resources at the Al Huda Islamic Boarding School in Gorontalo City in applying the Islamic Boarding School Accounting Guidelines. Pondok Pesantren (Islamic Boarding School) Al Huda was appointed by Bank Indonesia Gorontalo Representative Office as the pilot project for the pesantren which applies the Islamic Boarding School Accounting Guidelines. Based on the results of initial interviews, Al Huda Islamic Boarding School has been keeping financial records only to the extent of recording cash in and cash out. Al-Huda Islamic Boarding School has several other business entities such as Al-Huda Mart and a printing company in addition to its main business entity as Islamic boarding schools. It is necessary to do an in-depth study of the extent to which the Islamic Boarding School Accounting Guidelines have been applied to this pesantren. The research was carried out with the aim of describing how to apply the Accounting Guidelines for Islamic Boarding Schools, especially Al Huda Islamic Boarding School.

\section{Islamic Boarding School entities}

Pesantren is an Islamic educational institution that accommodates a number of santri (Islamic boarding school student) and female students in order to study religious sciences under the guidance of a kyai (Islamic scholar) (Suherman, 2019). In the Islamic boarding school the kyai becomes the central figure, the mosque is the center of activity, and Islamic teaching is under the guidance of the kyai. Every pesantren (Islamic boarding school) must have its own characteristics and cultivation, but this does not mean that pesantren institutions are completely different. There are still interrelated similarities between Islamic boarding schools, namely the system used by one pesantren is also applied in other pesantren (Afif, 2017).

According to the Indonesian Accounting Association's Islamic Boarding School Accounting Guidelines (2018) there are two types of business units at Islamic boarding schools, namely Type 1, where several Islamic boarding schools have business units that are part of the boarding school foundation legal entity and are managed independently by the Islamic

Copyright (C) 2020, Journal of Asian Multicultural Research for Economy and Management Study, 
boarding school. This business unit is included in the Islamic boarding school reporting entity. Type 2, in which the boarding school business unit stands alone as a separate legal entity, such as a cooperative, limited liability company, and other forms of legal entity. This type of business unit does not include the Islamic boarding school reporting entity.

\section{Islamic Boarding School Accounting Guidelines}

Islamic boarding school financial reports based on Islamic Boarding School Accounting Guidelines include financial position reports, activity reports, cash flow reports, and notes to financial reports. The statement of financial position provides information about assets, liabilities and net assets, as well as information about the relationship between these elements at a specific time. The financial position report uses information together with disclosures, as well as the information provided to help donors, creditors and other parties. The presentation of the report on the financial position of Islamic boarding schools is based on the Islamic Boarding School Accounting Guidelines as follows: (1) assets are presented based on their characteristics, grouped into current assets and non-current assets. (2) Liabilities are presented in order of maturity and classified into short-term and long-term liabilities. (3) Net assets are presented as binding net assets, unrestricted net assets and contemporary binding net assets.

Furthermore, the activity report. The information presented by the activity report is the financial performance of Islamic boarding schools during a certain period. Information about the effects of transactions and other events that change the amount and nature of net assets, the relationship between transactions and other events, and about the use of resources in the implementation of various programs or services.

Next is the Cash Flow Statement. The information presented in the cash flow statement is cash receipts and payments in a certain period. The flow statement is a summary of the company's cash receipts and payments during a certain period. The classification of cash receipts and disbursements at Islamic boarding schools is not different from business organizations, namely: cash and cash equivalents are classified into operating activities, investing activities and financing activities. Cash flows from operating activities come from fees, contributions, and changes in current assets and current liabilities, while investment cash flows record the impact of changes in fixed assets on cash. Last Notes on Financial Statements (CALK). The objective of the CALK is to provide additional, more detailed information about the estimates stated in the financial statements. This section cannot be separated from the financial reports that have been presented previously. CALK is presented systematically in order of presentation according to the main component.

\section{Methods}

Analyzing the preparation of financial reports at the Al-Huda Islamic Boarding School in Gorontalo City, with the main elements that must be in accordance with the problem formulation and research objectives, this research is a qualitative research. Pondok Pesantren Al-Huda, Gorontalo City Jl. Kiai Mojo, Limba B Village, Kota Selatan District, Gorontalo City, Gorontalo. The type of data used in this study is primary data obtained from the board of the Al-Huda Islamic Boarding School, in the form of records of financial management transactions at the Al-Huda Islamic Boarding School in Gorontalo City. Secondary data is data obtained indirectly, through intermediary media. In this study, it was pursued by using observation, interview, and documentation techniques. According to Creswell (2016) qualitative observation is when researchers go directly to the field to observe the behavior and activities of individuals at the research location. Apart from observation, this study uses

Copyright (C) 2020, Journal of Asian Multicultural Research for Economy and Management Study, 
interview techniques to collect data. This study uses unstructured interview techniques. The data to be obtained from unstructured interview techniques cannot be known with certainty, so that the object concerned will tell more about the existing problems, while the researcher listens carefully and records what the respondent says.

\section{Results and Discussion}

This research was conducted at Al Huda Islamic Boarding School, which is located in the middle of Gorontalo City with the aim of getting an idea of how the Islamic Boarding School Accounting Guidelines (PAP) is applied in the Islamic boarding school. Islamic Boarding School Accounting Guidelines is a product produced in collaboration with Bank Indonesia and the Indonesian Institute of Accountants (IAI). Islamic boarding school accounting guidelines have been socialized in 2019 to regional IAI representatives and representatives from Islamic boarding schools throughout Indonesia. The Gorontalo representative office of Bank Indonesia appointed the Al-Huda Islamic boarding school as an Islamic boarding school that had the opportunity to participate in the socialization with the hope that the AlHuda Islamic boarding school could begin to apply the pesantren's accounting guidelines as a basis for financial reporting.

Pondok Pesantren (Islamic Boarding School) Al Huda Gorontalo which was founded in 1927 has thousands of alumni spread across Indonesia and has played many roles in the world of education and preaching, especially in Gorontalo province. This is the reason why this Islamic boarding school has become a boarding school fostered by Bank Indonesia Gorontalo Representative Office. As a fostered Islamic boarding school, the management of the AlHuda Islamic boarding school is required to be more professional, especially in terms of financial recording. Islamic boarding school accounting guidelines were introduced to facilitate Islamic boarding schools in preparing financial reports based on generally accepted financial accounting standards in Indonesia, as well as providing added value for the advancement of Islamic boarding schools. The components of financial statements in the pesantren accounting guidelines include statements of financial position, reports of changes in net assets, cash flow reports, and notes to financial reports (Indonesian Accounting Association, 2020).

From the results of interviews with informants, it was found that the accounting records at the Al-Huda Islamic boarding school were still relatively simple and not in accordance with the pesantren's accounting guidelines. The financial statements based on the pesantren accounting guidelines consist of statements of financial position, reports of changes in net assets, cash flow reports, and notes to financial statements. Meanwhile, the Al-Huda Islamic boarding school has not compiled financial reports in accordance with the boarding school accounting guidelines. The treasurer of the Islamic boarding school is only limited to recording cash receipts and cash disbursements. The cash receipt transactions only come from the monthly fees of the students. Cash disbursement transactions include all operational expenses for Islamic boarding schools, including electricity, water, health costs, consumption costs, activity costs, and other operational costs, except for expenses for the construction of a dormitory building.

The Al Huda Gorontalo Islamic Education and Da'wah Foundation has 2 business charities and 6 schools, one of which is a boarding school. According to the pesantren accounting guidelines, independently managed business units that are still part of the boarding school foundation legal entity are included in the pesantren reporting entity. However, if the business unit stands alone as a separate legal entity, these business units are not included in the scope of the Islamic boarding school reporting entity (Indonesian Accounting 
Association, 2018). The Gorontalo Al-Huda Islamic Education and Da'wah Foundation has a policy of separating the reporting of its business units. The management of the boarding school reports its financial position to the leadership of the foundation, as well as other business units. So this is also the reason why accounting records at the Al-Huda Islamic boarding school are limited to recording cash books/cash flows in and out, because reporting responsibility is only to the leadership of the foundation, not the stakeholders.

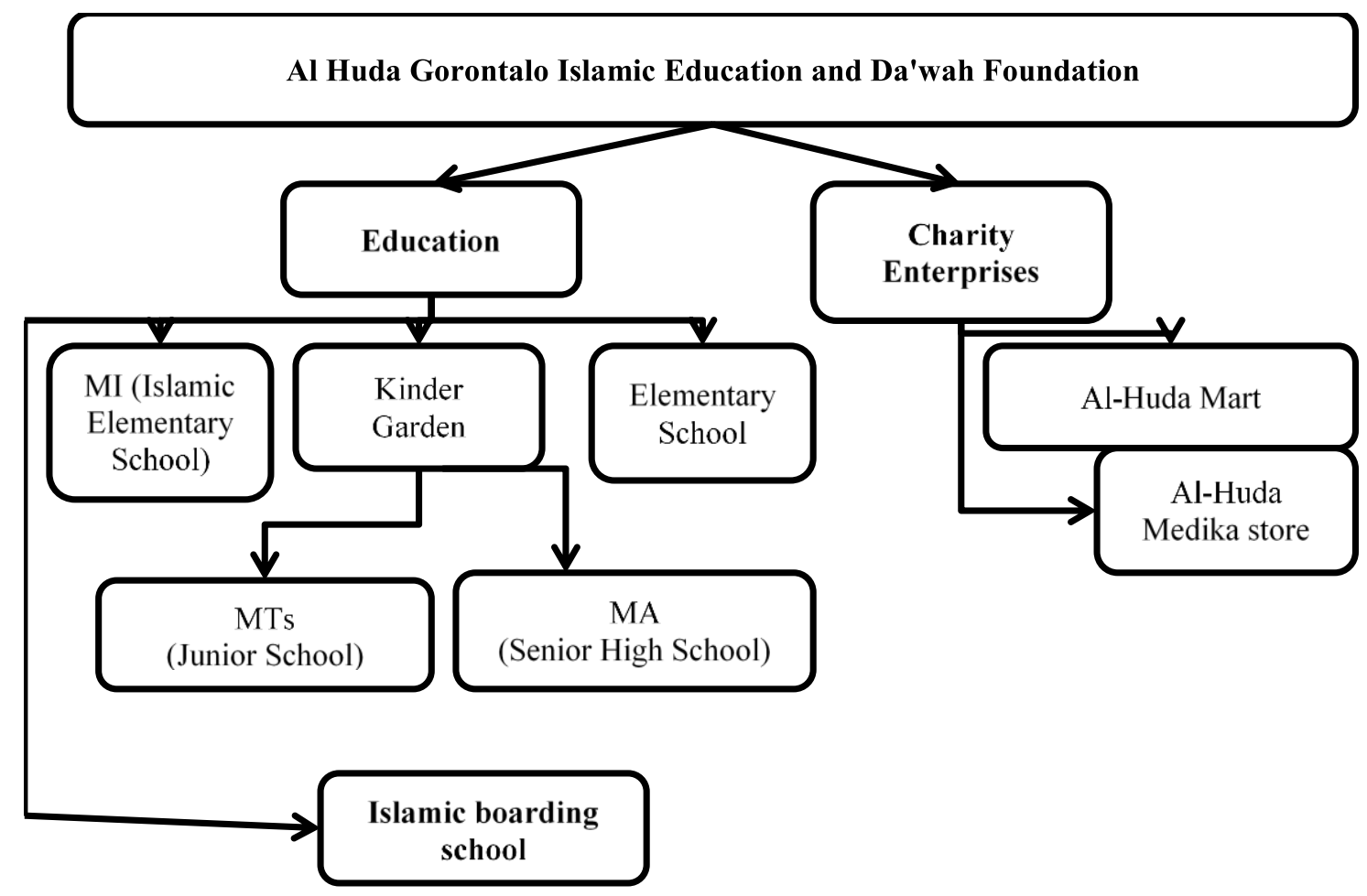

Figure 1. Structure of the Al-Huda Foundation

The Al Huda Gorontalo Islamic Education and Da'wah Foundation not only oversees the AlHuda Islamic boarding school, but also Kindergarten, Madrasah Ibtidaiyah, Elementary School (SD), Madrasah Tsanawiyah (MTs), Madrasah Aliyah (MA), Al-Huda Mart and Toko Al -Huda Medika (Picture 1). Financial policies are sometimes discussed together with the leaders and treasurers of business units, but decisions on these policies are returned to the leadership of the foundation. Management of Islamic boarding schools is limited to managing incoming funds which are obtained from the monthly fees of the students. If there is enough cash left, the boarding school treasurer pays the fee to the foundation. Likewise, if the boarding school lacks income due to the accumulation of arrears from students but on the other hand, it has to cover the fixed cost, the boarding school will get financial assistance / subsidies from the foundation. This kind of financial policy is usually carried out by the AlHuda foundation.

Regarding assets used by Islamic boarding schools such as mosque buildings, male dormitories, female dormitories, and several study rooms, according to the informants, they are on behalf of the foundation. However, in relation to this, it is still necessary to conduct a more detailed interview with the chairman of the foundation. Regarding the readiness of human resources for the application of Islamic boarding school accounting guidelines, the researcher found that there was a desire to apply these guidelines in the Al-Huda Islamic boarding school. Even though treasurers, secretaries and operators do not have a basic knowledge of the Economics of Accounting, the existing human resources are ready to apply

Copyright $@$ 2020, Journal of Asian Multicultural Research for Economy and Management Study, 
the pesantren (Islamic Boarding School) accounting guidelines, of course, adjusting to the needs of the Al-Huda Islamic boarding school.

The author sees that there is no urgency in implementing Islamic boarding school accounting guidelines at the Al-Huda Islamic boarding school because the reporting entity is the foundation that houses the Al-Huda Islamic boarding school, the Al Huda Islamic Education and Da'wah Foundation, Gorontalo. The foundation is fully responsible for the donors or the community. Foundations can prepare financial reports by referring to SAK ETAP or PSAK 45 financial reporting for non-profit entities.

The updating of Islamic boarding school accounting guidelines in 2020 is also an obstacle for researchers. There have been changes to the types of financial reports in the pesantren accounting guidelines issued in 2018 and in the draft for updating the Islamic boarding school accounting guidelines in 2020. The Indonesian Accounting Association has conducted public hearings and online socialization regarding the updating of the pesantren accounting guidelines. The fundamental thing that has changed is the type of financial report. In the 2018 pesantren accounting guidelines, pesantren financial reports include statements of financial position, activity reports, cash flow reports, and notes to financial reports. Meanwhile, the 2020 Islamic boarding school accounting guidelines consist of statements of financial position, reports of changes in net assets, cash flow reports, and notes to financial statements. There have also been changes in the classification of net assets and the way in which waqf assets are disclosed in the financial statements.

It is targeted that in 2020 the Al-Huda Islamic boarding school can implement the pesantren's accounting guidelines for financial reporting. Researchers attempt to introduce gradually to the management of Islamic boarding schools regarding pesantren accounting guidelines by providing pesantren accounting manuals and explaining important matters regarding pesantren accounting guidelines. The choice of implementing Islamic boarding school accounting guidelines is returned to the Al-Huda Islamic boarding school considering the use of Islamic boarding school accounting guidelines is not mandatory. The application of the pesantren accounting guidelines is returned to the need and urgency of reporting the pesantren itself.

The Indonesian Islamic Boarding School (SANTRI) Accounting System application is still under development this year by the Indonesian Accounting Association and BI in collaboration with the Gammatechno application developer. Changes in the accounting guidelines for pesantren have an effect on changes in the application system so that in order to share the SANTRI application with Islamic boarding schools in Indonesia, it is targeted to be completed in 2021 .

\section{Conclusion}

Accounting records at the Al-Huda Islamic boarding school are still relatively simple and not in accordance with the pesantren's accounting guidelines. The financial statements based on the pesantren accounting guidelines consist of statements of financial position, reports of changes in net assets, cash flow reports, and notes to financial statements. Meanwhile, the AlHuda Islamic boarding school has not compiled financial reports that are in accordance with the pesantren's accounting guidelines. The management of the boarding school reports its financial position to the leadership of the foundation, as well as other business units. So this is also the reason why accounting records at the Al-Huda Islamic boarding school are limited to recording cash books / cash flows in and out, because reporting responsibility is only to the leadership of the foundation. 


\section{References}

Bawono, A. (2019). Creative Economic Development of Pesantren. Shirkah: Journal of Economics and Business, 3(1).

Afif., R. F. (2017). Analisis Sistem Pengelolaan Keuangan di Pondok Pesantren Pesantren Terhadap Penguatan Manajemen Keuangan (Studi Kasus pada Pesantren Luhur AlHusna Surabaya). Thesis, Fakultas Ekonomi dan Bisnis Universitas Jember.

Suherman, L. P. (2019). Analisis Pentingnya Akuntansi Pesantren Bagi Pondok Pesantren AlMatuq Sukabumi. Jati: Jurnal Akuntansi Terapan Indonesia, 2(2), 65-70.

Ikatan Akuntansi Indonesia. (2017). Standar Akuntansi Keuangan. Jakarta: IAI.

Creswell, J. W. (2016). Research design: pendekatan metode kualitatif, kuantitatif, dan campuran. Yogyakarta: Pustaka Pelajar.

Fauzi, I. (2019). The Unique Characteristic of Teacher Development in Mu'adalah Pesantren of East Java. Madrosatuna: Journal of Islamic Elementary School, 3(2), 67-81.

Purwanto, M. R., \& Supriadi, R. (2019). The Use of Entrepreneurship Education in Community Empowerment at Lintangsongo Islamic Boarding School of Yogyakarta. International Journal of Engineering and Advanced Technology, 9, 796-799.

Sari, M. E. (2017). The role of learning management of Islamic boarding school (Pesantren) in improvement of their students religious tolerance in West JavaIndonesia. International Journal of Innovation and Applied Studies, 19(1), 24.

Herdiansyah, H., Jokopitoyo, T., \& Munir, A. (2016). Environmental awareness to realizing green Islamic boarding school (eco-pesantren) in Indonesia. In IOP Conference Series: Earth and Environmental Science, 30(1). 12017. IOP Publishing Ltd. 